\title{
Vitamin D and Its Role in Oral Diseases Development. Scoping Review
}

\author{
Ekaterina Diachkova 1,2,*(D), Daria Trifonova ${ }^{1}\left(\mathbb{D}\right.$, Elena Morozova ${ }^{1}$, Gyuzel Runova ${ }^{3}$, Igor Ashurko ${ }^{1}$, \\ Maria Ibadulaeva $^{3}{ }^{\circ}$, Valentin Fadeev ${ }^{3}$ and Svetlana Tarasenko ${ }^{1}$
}

1 Department of Oral Surgery of the Institute of Dentistry, I.M. Sechenov First Moscow State Medical University (Sechenov University), 119048 Moscow, Russia; trifonova030897@mail.ru (D.T.); lemua@yandex.ru (E.M.); ashurko@yandex.ru (I.A.); prof_tarasenko@rambler.ru (S.T.)

2 Department of Fundamental Medical Disciplines, Medical Faculty, Moscow Region State University (MRSU), Str. Radio 10, Build. 1, 105005 Moscow, Russia

3 Department of Endocrinology №1 of the Sklifosovsky Institute of Clinical Medicine, I.M. Sechenov First Moscow State Medical University (Sechenov University), 119048 Moscow, Russia; guzelvolkova@yandex.ru (G.R.); tmo-4509@mail.ru (M.I.); walfad@mail.ru (V.F.)

* Correspondence: secu2003@mail.ru; Tel.: +7-9265-199-342

check for updates

Citation: Diachkova, E.; Trifonova, D.; Morozova, E.; Runova, G.;

Ashurko, I.; Ibadulaeva, M.; Fadeev, V.; Tarasenko, S. Vitamin D and Its Role in Oral Diseases Development. Scoping Review. Dent. J. 2021, 9, 129. https://doi.org/10.3390/dj9110129

Academic Editor: Christian Bacci

Received: 19 September 2021

Accepted: 26 October 2021

Published: 2 November 2021

Publisher's Note: MDPI stays neutral with regard to jurisdictional claims in published maps and institutional affiliations.

Copyright: (C) 2021 by the authors. Licensee MDPI, Basel, Switzerland. This article is an open access article distributed under the terms and conditions of the Creative Commons Attribution (CC BY) license (https:/ / creativecommons.org/licenses/by/ $4.0 /)$.

\begin{abstract}
Vitamin D is a fat-soluble secosteroid that plays a significant role in the whole body, including the maxillofacial region. The discovery of its receptors in many cells and organs made it possible to reveal the participation of vitamin D not only in the regulation of calcium phosphate metabolism, but also in immune processes, in providing anti-inflammatory and antimicrobial effects, slowing down cell proliferation and stimulating differentiation. In this literature review, we demonstrate the association between low vitamin D levels and the development of recurrent aphthous stomatitis, the course and response to treatment of squamous cell carcinoma of the oral cavity, the severity of periodontal diseases, and the processes of osseointegration and bone remodeling during dental implantation and guided tissue regeneration. The aim of our article was to demonstate a possible connection between vitamin D level and the oral diseases that can be presented at an oral surgery appointment, which will help clinicians to reduce the risk of early dental implant failure, ensure favorable outcomes of augmentative operations, as well as decrease the destructive effects of severe periodontitis and other conditions throug knowledge and timely lab tests and endocrinologist prescriptions.
\end{abstract}

Keywords: vitamin D imbalance; osseointegration; dental implantation; maxillofacial region; oral diseases

\section{Introduction}

Vitamin D belongs to the group of fat-soluble secosteroid biomolecules. It is obtained in the body in two ways: alimentary (with food products and food additives intake) and through endogenous synthesis in the skin under UV radiation.

Worldwide vitamin D deficiency has increased interest in this compound, and therefore further study is warranted of its effect on various human organs and systems [1,2].

The most studied and effectively proven effects of vitamin D and its derivatives are the regulation of calcium phosphate metabolism and bone remodeling by enhancing intestinal absorption of calcium, increasing its reabsorption in the kidneys, and decreasing urinary secretion.

In addition, the discovery of vitamin D receptors in many cells and organs, for example, macrophages, monocytes, dendritic cells, cells of the placenta, the parathyroid gland and prostate, osteoblasts, smooth muscle cells and epithelial cells of the gingival attachment, contributed to the discovery of its "extra-osseous" effects [3,4]. A significant role of vitamin D has been proven in the immune processes, providing anti-inflammatory and antimicrobial effects, inhibiting cell proliferation, and stimulating differentiation.

The question of the effects of vitamin $\mathrm{D}$ on the oral cavity in modern dentistry remains poorly understood and requires further examination. 
The aim of our article was the demonstration of a possible connection between vitamin $\mathrm{D}$ level and the appearance and course of different oral diseases that can be presented in oral surgeries.

\section{Materials and Methods}

The electronic search was performed via the PubMed database (www.ncbi.nlm.nih. gov/pubmed, accessed on 25 October 2021), Google Academy (https:/ / scholar.google. $\mathrm{ru} / \mathrm{schhp}$ ?hl=ru, accessed on 25 October 2021) and the Cochrane Library, using a combination of keywords: "vitamin D deficiency", "oral cavity”, "osseointegration”, "dental implant", "periodontitis". The articles from 2011-2021 were included. Relevant papers were included after manual searches within included articles. The journals on implantation and periodontics were manually examined, with the aim of searching for articles. The search was limited to clinical research articles and literature reviews describing the possible connection between vitamin $\mathrm{D}$ level and oral diseases that can often be presented at an oral surgery appointment. In vitro and animal studies were excluded because the results of animal experiments cannot always be generalized to humans $[5,6]$.

\section{Vitamin D Metabolism}

There are two main native forms of vitamin D: vitamin D2 (ergocalciferol), which is contained in plants (yeast, mushrooms, crops) and enters the body only with food, and vitamin $\mathrm{D}_{3}$ (cholecalciferol), which is mostly synthesized in the skin from provitamin D3 (7-dehydrocholesterol) under the effects of sunlight. Another source of vitamin $\mathrm{D}_{3}$ is animals, such as wild salmon. Derivatives of vitamin D enter the extracellular matrix, and then bind to blood proteins in the bloodstream. Both forms are inactive and undergo further transformation in the body. Initially, hydroxylation occurs in the liver under the action of 25-hydroxylase transforming to $25(\mathrm{OH}) \mathrm{D}$ (calcidiol), which is the main circulating form of vitamin D. This indicator is used to quantify the serum level of vitamin D in clinical practice, since its half-life is up to 3 weeks [7]. According to the Russian Endocrine Society Clinical Practice Guideline, a level of vitamin D of $21-29 \mathrm{ng} / \mathrm{mL}(525-725 \mathrm{nmol} / \mathrm{liter})$ is considered as insufficient, a 25(OH)D level below $20 \mathrm{ng} / \mathrm{mL}$ (50 nmol/liter) is defined as deficiency, and a blood level above $30 \mathrm{ng} / \mathrm{mL}$ is interpreted as optimal [2].

The subsequent stage of vitamin D metabolism, catalyzed by 1-hydroxylase, occurs mainly in the kidneys and, to a lesser extent, in bone tissue, lungs, liver, parothyroide glands and keratinocytes. The result of this process is the formation of the biologically active form of vitamin $\mathrm{D}, 1,25$-dihydroxyvitamin $\mathrm{D}\left(1,25(\mathrm{OH})_{2} \mathrm{D}\right.$ or calcitriol), which is responsible for all the effects [7-9].

\section{Vitamin D Mechanism of Action}

The mechanism of action of the active form of vitamin $\mathrm{D}$ is similar to that of other steroid hormones, and is realized by its binding to the nuclear receptor [10]. $1,25(\mathrm{OH})_{2} \mathrm{D}$ is a high-affinity ligand for the vitamin D receptor (VDR), which is present not only in the intestines, bone tissue and kidneys-main organs responsible for calcium phosphate metabolism-but also in more than 38 different target organs [11]. Its binding leads to the formation of a hormone-receptor complex that modifies gene expression by linking its specific domain with the regulatory DNA sequence [12]. Thus, there is activation of the synthesis of some proteins (for example, calcium-binding protein, osteocalcin, osteopontin) and inhibition of others (proinflammatory cytokines: IL-6, IL-8) [13,14].

The gene encoding the VDR is located in the chromosome 12 in position $12 q 13.1$. The gene allele variations of VDR are relatively common in the population, with some differences between people of diverse ethnic groups. The polymorphism of the VDR gene may play a key role in the course of tumor progress, decreasing bone density, and increasing susceptibility to infections and autoimmune diseases, since it can influence the action of vitamin D on a cellular level, including calcium metabolism, transcription, cellular divisions and the initiation of the immunologic response $[8,15,16]$. 
A large number of studies have shown the correlation between low vitamin D levels and a number of different systemic diseases, i.e., diabetes mellitus, cardiovascular diseases (including coronary artery disease, congestive heart failure, valvular calcifications, stroke, arterial hypertension), autoimmune diseases (rheumatoid arthritis, systemic lupus erythematosus, multiple sclerosis, Crohn's disease), chronic kidney disease, and many others [17].

Vitamin D's regulation of calcium phosphate metabolism and bone remodeling, as well as its anti-inflammatory and immunomodulatory effects (regulation cell proliferation and differentiation), can significantly affect the health of the oral cavity [8,18-21]. A number of studies and reviews have demonstrated the association between low vitamin D levels and the course and frequency of recurrent aphthous stomatitis (RAS), the course and response to treatment of squamous cell carcinoma in the oral cavity, the severity of periodontal disease, and the processes of osseointegration and bone remodeling during dental implantation and guided tissue regeneration [18,22-32].

\section{Oral Mucosa}

\subsection{Recurrent Aphthous Stomatitis (RAS)}

Recurrent aphthous stomatitis (RAS) is a chronic mucosal disorder of the oral cavity, manifested in the presence of single painful erosions or ulcers of round or oval shape, with necrosis in the center and a hyperemia along the periphery. The etiology of this disease is still unknown, but dysregulation of the immune response is consider to be a risk factor, along with genetic defects, local trauma, emotional stress, and vitamin deficiency [18,33,34].

The significant role of vitamin $\mathrm{D}$ in the innate and acquired immune system, its ability to influence the synthesis of proinflammatory cytokines, and the presence of VDR on macrophages, dendritic cells, T- and B-lymphocytes, can explain the potential association with RAS $[19,22,23]$.

According to a few studies $[18,22,23,35]$, in patients with recurrent aphthous stomatitis, the level of serum $25(\mathrm{OH}) \mathrm{D}$ is significantly lower than in healthy people of similar ages and genders. Thus, Ainure Oztekin and Joshkun Oztekin [18] recommend vitamin D supplementation as a supportive treatment in patients with recurrent aphthous stomatitis. In the randomized clinical trial of Bakr Islam [36], a beneficial effect of topical oral vitamin $\mathrm{D}$ was demonstrated in its lowering of oral mucositis. However, in another study carried out by Krawiecka et al. [34], there was no significant difference in serum vitamin D levels (Table 1).

\subsection{Cancer Malignancy of the Oral Cavity}

One of the most common malignancies of the head and neck area is oral squamous cell carcinoma, with more than 300,000 new cases worldwide [37].

Molecular and cellular changes are associated with the influence of exogenous and endogenous factors (tobacco use or alcohol consumption, viral infections such as human papillomavirus (HPV), Epstein-Barr virus, hepatitis C virus, HIV) [38]. These multi-step processes contribute to the emergence of resistance to apoptosis in cancer stem cells, which prolongs their lifespans $[24,39]$. The disturbance of programmed cell death is a key factor in the carcinogenesis of squamous cell carcinoma of the oral cavity, and it manifests itself in a low response to radio- and chemotherapy as well as resistance to most anticancer drugs $[15,39]$.

In this regard, considerable interest has arisen in examining the chemopreventive and therapeutic potential of vitamin $\mathrm{D}$ and its derivatives [40].

The antitumor activity of $1,25-(\mathrm{OH})_{2} \mathrm{D}_{3}$ in a number of cells is provided by its ability to induce apoptosis, and to inhibit invasion, cell proliferation, and tumor angiogenesis [15,39,41,42].

In cancer cells, $1,25-(\mathrm{OH})_{2} \mathrm{D}_{3}$ activates inhibitors of cyclin-dependent kinases ( $\mathrm{p} 21$, p27) and mitogenic growth factors (IGF-1, EGF), and promotes the activation of TGF- $\beta$, thus exhibiting antiproliferative properties [43]. 
According to Udeabor S.E. et al. (2020) [24], more than $74 \%$ of patients with squamous cell carcinoma of the oral cavity showed a decrease in serum vitamin D levels compared with a control group with no history of cancer. A positive association between the risk of squamous cell carcinoma and vitamin D deficiency, especially at levels below $25 \mathrm{ng} / \mathrm{ml}$, increases the likelihood of developing a malignant neoplasm by 1.65-fold [24].

Anand et al. concluded that patients with oral squamous cell carcinoma, who received vitamin $\mathrm{D}_{3}$ at a dose of 1000 International Units (IU) per day for 3 months, showed a reduction in the adverse effects associated with chemotherapy. There was a decrease in the severity of oral mucositis (a decrease in hyperemia, edema, ulceration, and pain), an improvement in swallowing function, and an increase in the quality of life compared with patients who did not receive vitamin $\mathrm{D}_{3}$ [15]. The same conclusion was reached by Mostafa et al. based on the results of their research [44]. 
Table 1. Literature analysis of vitamin D level and oral mucosa diseases connection.

\begin{tabular}{|c|c|c|c|c|c|c|c|c|}
\hline Author, Year & Pathology & Patients, Age & Vitamin D Level & Diagnostics of Vitamin D Imbalance & $\begin{array}{l}\text { Treatment of Vitamin } \\
\text { D Imbalance }\end{array}$ & $\begin{array}{l}\text { Vitamin D } \\
\text { Level }\end{array}$ & Positive Results-Main Pathology & Probability \\
\hline \multicolumn{9}{|c|}{ RCT } \\
\hline $\begin{array}{l}\text { Bakr SI et al., } \\
2020[36]\end{array}$ & $\begin{array}{l}\text { The effectiveness of } \\
\text { topical oral vitamin } \\
\text { D gel in prevention } \\
\text { of radiation induced } \\
\text { oral mucositis }\end{array}$ & 45, Absent & $<20 \mathrm{ng} / \mathrm{mL}$ & Vitamin D serum evaluation & $\begin{array}{l}\text { Topical vitamin D oral } \\
\text { gel, every } 1 \mathrm{~g} \text { of the gel } \\
\text { contains } 4000 \text { IU. It was } \\
\text { given twice daily. }\end{array}$ & Absent & $\begin{array}{l}\text { Topical oral vitamin } \mathrm{D} \text { gel has a beneficial } \\
\text { effect in lowering oral mucositis } \\
\text { development and in reducing pain } \\
\text { sensation during the radiation period, } \\
\text { especially when combined with } \\
\text { conventional therapeutic agents. }\end{array}$ & $p<0.05$ \\
\hline $\begin{array}{l}\text { Lalla RV et al., } \\
2012[45]\end{array}$ & $\begin{array}{l}\text { Recurrent aphthous } \\
\text { stomatitis }\end{array}$ & $160,>18$ & Absent & Absent & $\begin{array}{l}\text { A generic multivitamin } \\
\text { supplement containing } \\
\text { only the U.S. reference } \\
\text { daily intake (RDI) of } \\
\text { the essential vitamins } \\
\text { A, B1, B2, B3, B5, B6, B9, } \\
\text { B12, C, D and E. }\end{array}$ & Absent & $\begin{array}{l}\text { Daily multivitamin supplementation, with } \\
\text { the RDI of essential vitamins, did not } \\
\text { result in a reduction in thenumber or } \\
\text { duration of RAS episodes. }\end{array}$ & $p=0.69$ \\
\hline \multicolumn{9}{|c|}{ Others } \\
\hline $\begin{array}{l}\text { Bahramian A et al., } \\
2018 \text { [22] }\end{array}$ & $\begin{array}{l}\text { Recurrent aphthous } \\
\text { stomatitis }\end{array}$ & $52,18-60$ & $33.0 .7 \pm 12.41 \mathrm{ng} / \mathrm{dL}$ & $\begin{array}{l}\text { The electrochemiluminescence } \\
\text { technique }\end{array}$ & Absent & Absent & $\begin{array}{l}\text { The serum levels of vitamin D in patients } \\
\text { with RAS were significantly lower than } \\
\text { those in healthy individuals. }\end{array}$ & $p<0.001$ \\
\hline $\begin{array}{l}\text { Öztekin A et al., } \\
2018 \text { [18] }\end{array}$ & $\begin{array}{l}\text { Recurrent aphthous } \\
\text { stomatitis }\end{array}$ & $110,>18$ & $11.00 \pm 7.03 \mathrm{ng} / \mathrm{mL}$ & $\begin{array}{l}\text { The electrochemiluminescence } \\
\text { binding method (COBAS reagent kit; } \\
\text { COBAS e601 analyzer series, Roche } \\
\text { Diagnostics, Basel, Switzerland) }\end{array}$ & Absent & Absent & $\begin{array}{l}\text { Lower vitamin } D \text { levels in patients with } \\
\text { recurrent aphthous stomatitis compared } \\
\text { to healthy controls. }\end{array}$ & $p=0.004$ \\
\hline $\begin{array}{l}\text { Udeabor SE et al., } \\
2020[24]\end{array}$ & $\begin{array}{l}\text { Oral squamous cell } \\
\text { carcinoma (OSCC) }\end{array}$ & $51,59.33 \pm 12.54$ & $20.42 \pm 12.02$ & Absent & Absent & $>35 \mathrm{ng} / \mathrm{mL}$ & $\begin{array}{l}\text { A positive association between vitamin } \mathrm{D} \\
\text { deficiency and OSCC risk. } \\
\text { Vitamin D does not seem to be a trigger }\end{array}$ & $p=0.001$ \\
\hline $\begin{array}{l}\text { Krawiecka E et al., } \\
2017[34]\end{array}$ & $\begin{array}{l}\text { Recurrent aphthous } \\
\text { stomatitis }\end{array}$ & $66,34.15 \pm 12.26$ & $16.81 \mathrm{ng} / \mathrm{mL}$ & $\begin{array}{l}\text { The electro-chemiluminescence } \\
\text { binding assay (ECLIA) }\end{array}$ & Absent & $30-50 \mathrm{ng} / \mathrm{mL}$ & $\begin{array}{l}\text { factor for RAS occurrence and does not } \\
\text { appear to influence the severity of the } \\
\text { disease in the studied group. }\end{array}$ & $p=0.2073$ \\
\hline $\begin{array}{l}\text { Grimm M et al., } \\
2015[39]\end{array}$ & $\begin{array}{l}\text { Oral squamous cell } \\
\text { carcinoma (OSCC) }\end{array}$ & 42, Absent & $12.2 \mathrm{ng} / \mathrm{mL}$ & $\begin{array}{l}\text { The radioimmunoassay at Biovis } \\
\text { laboratory (Limburg-Offheim, } \\
\text { Germany) }\end{array}$ & Absent & $>35 \mathrm{ng} / \mathrm{mL}$ & $\begin{array}{l}\text { A significantly increased expression of } \\
\text { VDR was observed in tumor cells of } \\
\text { OSCC. }\end{array}$ & $p<0.05$ \\
\hline $\begin{array}{l}\text { Anand A et al., } \\
2017 \text { [15] }\end{array}$ & Oral neoplasms & $110,42.67 \pm 10.83$ & $\begin{array}{l}-1.90 \pm 0.43 ; \text { range } \\
-3 \text { to } 0\end{array}$ & $\begin{array}{l}\text { The chemiluminescent immunoassay } \\
\text { method } \\
\text { The enzyme-linked immunosorbent }\end{array}$ & $\begin{array}{l}1000 \text { IU BD per day for } \\
3 \text { months }\end{array}$ & $30-100 \mathrm{ng} / \mathrm{mL}$ & $\begin{array}{l}\text { Vitamin D scores were significantly lower } \\
\text { in cases compared to healthy controls. }\end{array}$ & $p=0.002$ \\
\hline $\begin{array}{l}\text { Zakeri M et al., } \\
2021[35]\end{array}$ & $\begin{array}{l}\text { Recurrent aphthous } \\
\text { stomatitis }\end{array}$ & $86,15-40$ & $13.19 \pm 8.19 \mathrm{ng} / \mathrm{mL}$ & $\begin{array}{l}\text { assay (ELISA), using a laboratory kit } \\
\text { (Cat. No. EUROIMMUN, EQ. } \\
\text { 6411-9601; PerkinElmer, Lübeck, } \\
\text { Germany) }\end{array}$ & Absent & $30-50 \mathrm{ng} / \mathrm{mL}$ & $\begin{array}{l}\text { The serum levels of vitamin D are lower in } \\
\text { patients with RAS in comparison with } \\
\text { healthy controls. }\end{array}$ & $p=0.002$ \\
\hline $\begin{array}{l}\text { Mostafa B El-D } \\
\text { et al., } 2015 \text { [44] }\end{array}$ & $\begin{array}{l}\text { Head and neck } \\
\text { squamous cell cancer }\end{array}$ & $80,54.8 \pm 12.7$ & $\begin{array}{l}\text { The median- } \\
40.35 \mathrm{ng} / \mathrm{mL}\end{array}$ & $\begin{array}{l}\text { The enzyme-linked immunosorbent } \\
\text { assay (ELISA) technique using } \\
\text { CALBIOTECH ELISA kit for Human } \\
\text { VD3 Immunoassay (catalog no: } \\
\text { VD220B; Calbiotech, Spring Valley, } \\
\text { California, USA) }\end{array}$ & Absent & $>80 \mathrm{nmol} / 1$ & $\begin{array}{l}\text { Vitamin D deficiency is prominent in } \\
\text { patients with head and neck squamous } \\
\text { cell carcinoma before treatment compared } \\
\text { to controls. }\end{array}$ & $p<0.001$ \\
\hline
\end{tabular}




\section{Periodontal Diseases}

In modern dentist's practice, the problem of chronic generalized periodontitis is quite acute. This is due not only to the high prevalence of this pathology among the population-98\% - but also to the lack of the expected effect of treatment [46].

Quite often, dentists are faced with resistance to the treatment of chronic generalized periodontitis, a decrease in the duration of stable remission and an increase in the aggressive course of periodontitis. The presented problems demonstrate the need for a more thorough study of the components of the pathogenesis of chronic generalized periodontitis, and the search for means of complex treatment [46].

Periodontitis is characterized by damage to the tissues surrounding the tooth, caused by the host's immune inflammatory response to bacterial invasion. Since vitamin D plays an essential role in the metabolism of bone tissue and maintenance of the immune response, it is reasonable to suppose that its deficiency may affect the pathogenesis of the disease and the state of the periodontium [47,48].

The active metabolite of vitamin $\mathrm{D}-1,25(\mathrm{OH})_{2} \mathrm{D}_{3}$-is involved in specific immune defense and has an anti-inflammatory effect, acting on T- and B-lymphocytes, inhibiting the production of pro-inflammatory IL-6 and IL-8, which are involved in the development of acute inflammation [48-51].

The regulation of the nonspecific immune response occurs by stimulating the synthesis of antimicrobial peptides (defensins and cathelicidin) through vitamin D receptors (VDR), which have been found in monocytes, macrophages, neutrophils, and dendritic cells.

One of the defensins, beta-defensin 2, exhibits antimicrobial activity against oral pathogens, including bacteria associated with the development of periodontitis (Porphyromonas gingivalis, Fusobacterium nucleatum, and Aggregatibacter actinomycetemcomitans) $[16,27]$.

The analysis of observations provided by Bashutski JD et al. [47] demonstrated that vitamin D deficiency leads to less effective outcomes after periodontal surgery (lower soft tissue attachment and changes in probing depth).

Pinto et al. [52] in their systematic review argued that the relation between periodontal disease and vitamin D deficiency may be justified, but most studies have significant limitations, which prevents the confirmation of the existence of this association.

Research by Isola et al. [28], as well as Anbarcioglu E et al. [27], showed that patients with periodontitis had lower serum vitamin D levels compared to healthy patients. Moreover, vitamin D deficiency negatively influenced the course of periodontal disease and increased the risk of aggressive periodontitis. Since this study confirms a relation between low serum vitamin D levels and the development of periodontitis, according to the authors, vitamin D assessment should be recommended at the beginning of periodontal therapy, as it may reduce the risk of developing this disease [28].

In addition to the above, the study by Garcia et al. demonstrates that calcium and vitamin D supplementation (1000 IU/day) had a moderate positive effect on periodontal health and improved clinical parameters [53]. The studies of Gao et al. and Meghil confirmed that supplementation with vitamin D significantly raised its serum level, improved such periodontal parameters as attachment loss and probing depth, and reduced systemic inflammation $[54,55]$. These results confirm the possibility of a positive effect of vitamin D on periodontal health (Table 2). 
Table 2. Literature analysis of vitamin D level and periodontal diseases connection.

\begin{tabular}{|c|c|c|c|c|c|c|c|c|}
\hline Author, Year & Pathology & Patients, Age & Vitamin D Level & $\begin{array}{l}\text { Diagnostics of Vitamin } \\
\text { D Imbalance }\end{array}$ & $\begin{array}{l}\text { Treatment of } \\
\text { Vitamin D } \\
\text { Imbalance }\end{array}$ & $\begin{array}{l}\text { Vitamin D } \\
\text { Level }\end{array}$ & Positive Results-Main Pathology & Probability \\
\hline \multicolumn{9}{|c|}{ RCT } \\
\hline $\begin{array}{l}\text { Hiremath VP et al., } \\
2013 \text { [56] }\end{array}$ & Gingivitis & $96,18-64$ & $20-65 \mathrm{ng} / \mathrm{mL}$ & $\begin{array}{l}\text { Direct Elisa kit } \\
\text { (Immunotek; Bensheim, } \\
\text { Germany) }\end{array}$ & $\begin{array}{l}2000 \mathrm{IU} / \text { day, } \\
1000 \mathrm{IU} / \text { day, } \\
500 \mathrm{IU} / \text { day } \\
\text { or placebo }\end{array}$ & Absent & $\begin{array}{l}\text { Vitamin D has an anti-inflammatory } \\
\text { effect in doses ranging from } \\
500 \text { to } 2000 \mathrm{IU}\end{array}$ & $p<0.001$ \\
\hline \multicolumn{9}{|c|}{ Others } \\
\hline $\begin{array}{l}\text { Meghil MM et al., } \\
2019 \text { [55] }\end{array}$ & $\begin{array}{l}\text { Generalized chronic } \\
\text { moderate to severe } \\
\text { periodontitis }\end{array}$ & $23,44.8 \pm 9.4$ & Non-deficient & $\begin{array}{l}\text { Enzyme immunoassay } \\
\text { (Immunodiagnostic } \\
\text { Systems, Fountain Hills, } \\
\text { AZ, USA) }\end{array}$ & $\begin{array}{l}4000 \mathrm{IU} / \text { day oral } \\
\text { Vitamin D } \\
\text { supplementation for } \\
16 \text { weeks }\end{array}$ & Absent & $\begin{array}{l}\text { An important role for vitamin D } \\
\text { supplementation in inducing local } \\
\text { and systemic anti-inflammatory } \\
\text { response and enhancing the } \\
\text { autophagic profile in PD patients } \\
\text { after scaling and root planning }\end{array}$ & $p<0.001$ \\
\hline $\begin{array}{l}\text { Bashutski JD et al., } \\
2011 \text { [47] }\end{array}$ & $\begin{array}{l}\text { Periodontal surgery } \\
\text { and teriparatide } \\
\text { administration in } \\
\text { patients with severe } \\
\text { chronic periodontitis }\end{array}$ & $40,30-65$ & $\begin{array}{l}28 \% \text { of enrolled } \\
\text { participants presenting } \\
\text { with mild deficiency } \\
(16-19 \mathrm{ng} / \mathrm{mL}), \\
\text { participants with } \\
\text { moderate to severe } \\
\text { deficiency were excluded }\end{array}$ & Serum vitamin D level & $\begin{array}{l}\text { Daily } 1000 \mathrm{mg} \\
\text { calcium and } 800 \mathrm{IU} \\
\text { vitamin D oral } \\
\text { supplements was } \\
\text { initiated } 3 \text { days prior } \\
\text { to surgery and } \\
\text { continued for } \\
6 \text { weeks }\end{array}$ & $20-74 \mathrm{ng} / \mathrm{mL}$ & $\begin{array}{l}\text { It is advisable to ensure adequate } \\
\text { vitamin D levels well in advance of } \\
\text { periodontal surgery, to attain the } \\
\text { best possible results }\end{array}$ & $p<0.01$ \\
\hline $\begin{array}{l}\text { Emrah A et al., } \\
2018 \text { [27] }\end{array}$ & $\begin{array}{l}\text { The association } \\
\text { between vitamin D } \\
\text { concentration and } \\
\text { both aggressive and } \\
\text { chronic periodontitis }\end{array}$ & $129,21-47$ & $\begin{array}{l}11.22 \pm 4.8 \mathrm{ng} / \mathrm{mL}- \\
\text { aggressive periodonti- } \\
\text { tis } 16.13 \pm 8.3 \mathrm{ng} / \mathrm{mL}- \\
\text { chronic periodontitis }\end{array}$ & $\begin{array}{l}\text { Liquid } \\
\text { chromatography-mass } \\
\text { spectrometry } \\
\text { (LC-MS/MS) (München, } \\
\text { Germany). }\end{array}$ & Absent & $>20 \mathrm{ng} / \mathrm{mL}$ & $\begin{array}{l}\text { The study showed that lower } \\
25(\mathrm{OH}) \mathrm{D} \text { concentrations were } \\
\text { associated with a higher risk of } \\
\text { aggressive periodontitis }\end{array}$ & $p<0.0002$ \\
\hline
\end{tabular}


Table 2. Cont

\begin{tabular}{|c|c|c|c|c|c|c|c|c|}
\hline Author, Year & Pathology & Patients, Age & Vitamin D Level & $\begin{array}{l}\text { Diagnostics of } \\
\text { Vitamin D } \\
\text { Imbalance }\end{array}$ & $\begin{array}{l}\text { Treatment of } \\
\text { Vitamin D } \\
\text { Imbalance }\end{array}$ & $\begin{array}{l}\text { Vitamin D } \\
\text { Level }\end{array}$ & $\begin{array}{l}\text { Positive Results-Main } \\
\text { Pathology }\end{array}$ & Probability \\
\hline $\begin{array}{l}\text { Isola G et al., } \\
2019 \text { [28] }\end{array}$ & $\begin{array}{l}\text { The association } \\
\text { between serum } \\
\text { vitamin D levels and } \\
\text { periodontitis in } \\
\text { patients with chronic } \\
\text { periodontitis (CP) and } \\
\text { coronary heart disease } \\
\text { (CHD) }\end{array}$ & $179, \geq 18$ & $\begin{array}{l}\mathrm{CP}-17.4 \pm 5.2 \\
\mathrm{ng} / \mathrm{mL} \mathrm{CP}+\mathrm{CHD}- \\
16.5 \pm 5.6 \mathrm{ng} / \mathrm{mL}\end{array}$ & $\begin{array}{l}\text { Serum vitamin D } \\
\text { level }\end{array}$ & Absent & $\geq 20 \mathrm{ng} / \mathrm{mL}$ & $\begin{array}{l}\text { Patients with } \mathrm{CP} \text { and } \mathrm{CP}+\mathrm{CHD} \\
\text { presented significantly lower serum } \\
\text { levels of vitamin D compared to } \\
\mathrm{CHD} \text { and healthy controls }\end{array}$ & $p<0.001$ \\
\hline $\begin{array}{l}\text { Laky M et al., } \\
2019 \text { [48] }\end{array}$ & $\begin{array}{l}\text { The association } \\
\text { between vitamin D } \\
\text { concentration and } \\
\text { periodontal diseases }\end{array}$ & $58,35.41 \pm 7.7$ & Absent & $\begin{array}{l}\text { An enzyme- } \\
\text { immunoassay, } \\
\text { EIASON } \\
\text { 25-OH-VitaminD }{ }^{\circledR} \\
\text { test kit, IASON } \\
\text { GmbH, Graz, } \\
\text { Austria }\end{array}$ & Absent & $>30 \mathrm{ng} / \mathrm{mL}$ & $\begin{array}{l}25(\mathrm{OH}) \mathrm{D} \text { deficiency } \\
\text { is significantly associated with } \\
\text { periodontal disease }\end{array}$ & $p<0.05$ \\
\hline $\begin{array}{l}\text { Agrawal AA et al., } \\
2019 \text { [50] }\end{array}$ & $\begin{array}{l}\text { The association } \\
\text { between the levels of } \\
\text { vitamin D and calcium } \\
\text { in the serum of } \\
\text { periodontally healthy, } \\
\text { chronic gingivitis and } \\
\text { chronic periodontitis } \\
\text { patients with and } \\
\text { without type-2 } \\
\text { diabetes mellitus }\end{array}$ & $100,30-50$ & $\begin{array}{l}\text { chronic gingivitis- } \\
49.05 \mathrm{ng} / \mathrm{mL} \text { chronic } \\
\text { periodontitis- } \\
26.94 \mathrm{ng} / \mathrm{mL}\end{array}$ & ELISA kit & Absent & Absent & $\begin{array}{l}\text { Vitamin D and calcium levels are } \\
\text { inversely correlated with random } \\
\text { blood sugar and } \\
\text { glycosylated hemoglobin, and, also } \\
\text { probing pocket depth and clinical } \\
\text { attachment loss, thus may } \\
\text { contribute to increases in the } \\
\text { severity of periodontal } \\
\text { disease activity }\end{array}$ & $p<0.05$ \\
\hline $\begin{array}{l}\text { Garcia MN et al., } \\
2011 \text { [53] }\end{array}$ & $\begin{array}{l}\text { Vitamin D and calcium } \\
\text { supplementation for } \\
\text { better periodontal } \\
\text { health compared to } \\
\text { patients not taking it }\end{array}$ & $\begin{array}{l}\text { 51, postmenopausal } \\
\text { fem., males } 50-80\end{array}$ & Absent & Nutritional analysis & $\begin{array}{l}\text { Vitamin } \mathrm{D}(400 \\
\mathrm{IU} / \text { day }) \text { and } \\
\text { calcium } \\
(1000 \mathrm{mg} \text { /day })\end{array}$ & $\begin{array}{l}125 \text { to } 175 \\
\mathrm{nmol} / \mathrm{L}\end{array}$ & $\begin{array}{l}\text { Calcium and vitamin D } \\
\text { supplementation (1000 IU/day) } \\
\text { had a modest positive effect on } \\
\text { periodontal health }\end{array}$ & $p=0.058$ \\
\hline
\end{tabular}




\section{Osseointegration}

The most studied and proven effect of vitamin D is the regulation of calcium phosphate homeostasis and bone remodeling, which is realized through an increase in the intestinal absorption of calcium, its reabsorption in the renal tubules, the suppression of the synthesis and secretion of parathyroid hormone, the activation of osteoclasts, increases in the production of extracellular matrix by osteoblasts and the expression of genes of osteocalcin, osteopontin, calbindin and 24-hydroxylase [57-62]. Based on these data, vitamin D may play an essential role in bone regeneration during dental implantation and osteoplastic surgery (Table 3).

Today, implantology is developing with great pace, and dental implants have become a reliable way to rehabilitate missing teeth with functional and aesthetic results. The achievement of the long-term stable functioning of dental implants is ensured by their osseointegration, which is characterized by a direct strong connection between the bone and the implant surface in the absence of fibrous tissue. This phenomenon depends on many factors: the material, design and surface of the implant, the surgical technique and prosthodontic treatment protocol, as well as the quality of the bone and the regenerative capabilities of the body $[63,64]$.

The process of the osseointegration of dental implants, which consists of several stages of bone remodeling, is accompanied by the active osteoclastic resorption of undifferentiated bone tissue $[65,66]$. Bone formation after osteoplastic operations occurs through the resorption of the graft and the replacement of the graft with the patient's own bone tissue [25]. In these metabolic processes, osteoclasts play an active role along with osteoblasts [65].

Since the osseointegration of dental implants depends on the ability of bone to regenerate, it is assumed that the healing process and the formation of bone tissue around the implant are reduced with vitamin D deficiency [60,63,67-69].

Fretwurst et al. [57] demonstrated two clinical cases of early dental implant failure in patients with vitamin D deficiency. Both patients reported no systemic desease, were non-smokers, and took niether drugs nor alcohol. The clinical conditions were the same, so all implants were inserted with the torque $<35 \mathrm{Ncm}$, and primary stability was achieved. The surgical procedure was accompanied by a sufficient irrigation and surgical protocol. The results of the study show successful subsequent implant placement after vitamin $D$ supplementation, and the restoration of its adequate level in the blood.

According to a case report of Bryce $G$ and MacBeth N [26], a severe vitamin D deficiency in a patient who had undergone a single-stage implantation might have contributed to the absence of osseointegration five month post-operatively, and dental implant failure.

In observations reported by Schulze-Späte et al. [25], there is a significant correlation between increased serum vitamin D levels and the presence of osteoclasts around graft particles during augmentation. This may suggest a more pronounced metabolic activity, which promotes local remodeling in the augmentation area.

Moreover, Amr et al. [70] demonstrated the effect of vitamin D mixed with xenografts in alveolar bone augmentation. A statistically significant difference was observed in enhancing the bone formation and improving implant stability.

The benefits of vitamin D were demonstrated in a study by Kwiatek J. et al. [71]. The bone level around the implant was significantly higher in patients who took vitamin D supplements, which allows us to suggest that this biomolecule is a potential factor that stimulates the remodeling process and the growth of bone tissue around the dental implant.

The level of crestal bone loss around the dental implant is one of the accepted methods for assessing its long-term survival. A significant correlation between the amount of marginal bone in patients with vitamin D deficiency who were supplemented with vitamin $\mathrm{D}$ and those who have not received it was observed in the study by Garg P et al. [62]. The authors concluded that normal levels of serum vitamin D can help to prevent the risk of early dental implant failure, enhance osseointegration and the healing process.

However, Javed et al. [60] and Boas et al. [72] suggested that the effect of vitamin D levels on implant osseointegration is still controversial. 
Mangano et al. [59,73], in their retrospective clinical studies, noted a tendency towards an increased risk of early dental implant failure in patients with severe vitamin D deficiency. However, it was not possible to prove the relationship between these facts, since no statistically significant difference was demonstrated.

The success of a dental implant treatment is defined by both the achievement of osseointegration and peri-implant tissue health. Hence, Piccolotto A et al. [74] demonstrated differences in such parameters as the width of keratinized mucosa, bleeding index, probing depth, and the level of mesial and distal bone crest, depending on vitamin $\mathrm{D}$ status. According to this study, vitamin D supplementation for patients with deficiency has not manifested a statistically significant difference in clinical peri-implant tissue health, and the level of bone crest was classified as within the limits of the success criteria. However, it is worth taking into account that implant rehabilitation treatment had already been completed more than a year before the study, and vitamin D administration had been ongoing for 2 months.

According to some studies [73,75], the preoperative monitoring of serum $25(\mathrm{OH}) \mathrm{D}$ levels and, if necessary, the prescribing of oral vitamin D for several weeks before surgical intervention can accelerate the healing process and prevent early implant failure.

Vitamin D can influence osseointegration through the processes associated with healing and the marginal seals of soft tissues surrounding the implant and can help to reduce the development of bacterial infections and peri-implantitis [76,77]. The results of Acipinar S. et al.'s study [78] confirmed a significant decrease in serum 25(OH)D in a peri-implantitis group compared with a healthy control group. 
Table 3. Literature analysis of vitamin D level and dental implantation connection.

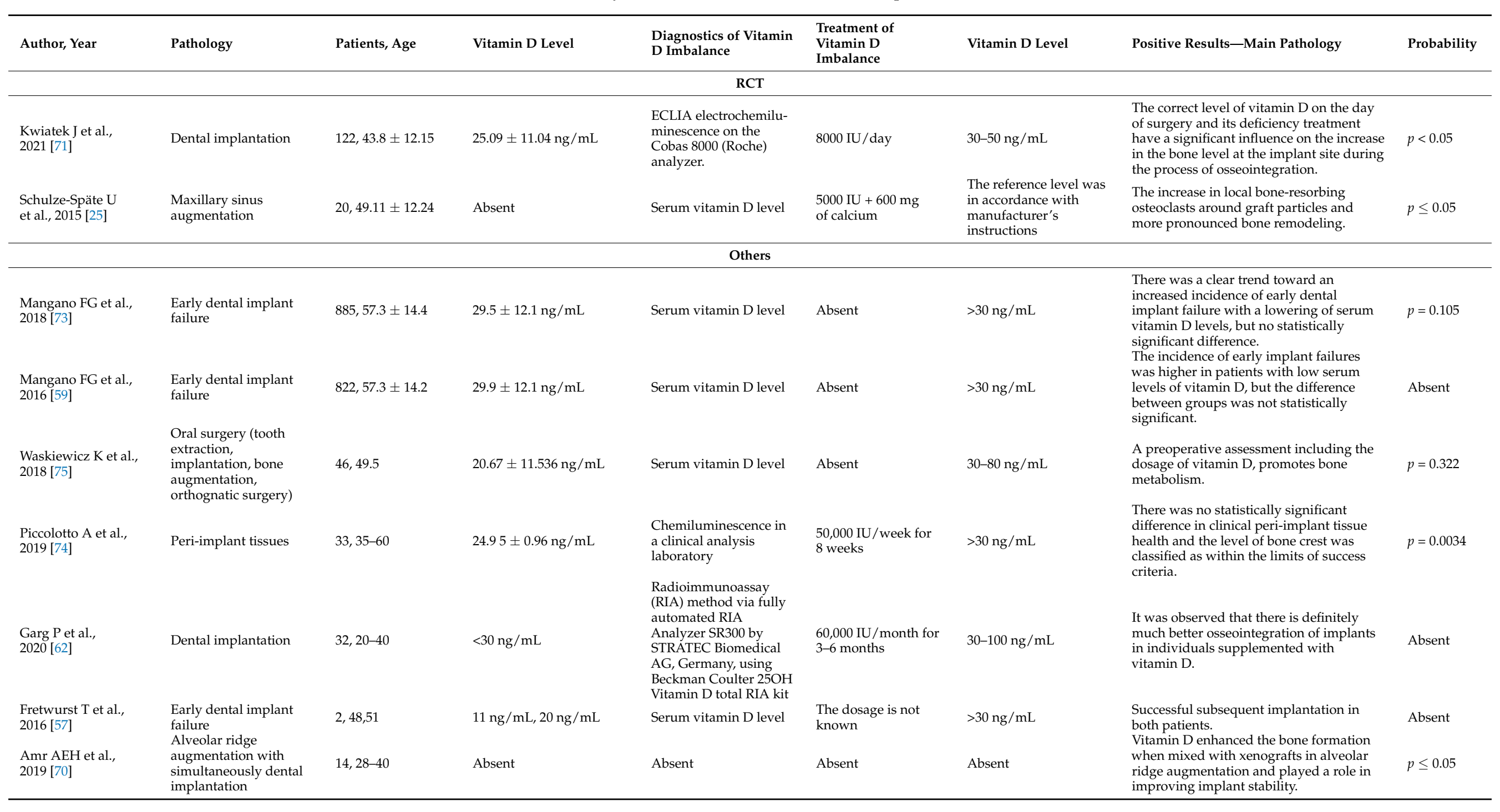




\section{Medication-Related Osteonecrosis of the Jaw}

Medication-related osteonecrosis of the jaw (MRONJ) is a condition of the oral cavity resulting in the exposure of underlying necrotic bone, persisting for more than 8 weeks, and it is a severe late complication of bisphosphonates, denosumab and antiangiogenics in the treatment of cancer-related conditions and osteoporosis [79]. Initially, only bisphosphonaterelated osteonecrosis of the jaw (BRONJ) was described in the literature. However, in 2014, the American Association of Oral and Maxillofacial Surgeons recommended the change in the nomenclature of BRONJ to MRONJ, as it was found that other antiresorptives, such as denosumab, and antiangiogenic medications cause similar complications [80-82]. The pathophysiology of MRONJ is not completely understood, so its prevention and management remain challenging today.

Some of the risk factors strongly associated with MRONJ for patients undergoing antiresorptive therapy are infection and mechanical trauma after tooth extraction; moreover, some researchers have observed that a low vitamin $\mathrm{D}$ level also may be a risk factor for the development of MRONJ [80,83].

According to the study by Bedogni A. et al. [84], the hypothesis that vitamin D deficiency is more common in BRONJ+ than in BRONJ- patients is unlikely to be true. Even though the patients were matched for age and sex, and not all of them were supplemented with vitamin $\mathrm{D}$, there are no significant differences in BRONJ+ and BRONJ- groups.

On the contrary, Demircan S. and Isler S.C. [85] demonstrated a significant association between vitamin D levels and MRONJ in their study. There was statistically lower vitamin D level than in the control group. The authors suggest that the clinician should follow up changes in biochemical markers of bone metabolism when managing oral surgery patients on bisphosphonates. However, there is a need for more studies of vitamin D levels, which will be evaluated separately.

A retrospective investigation by Heim $\mathrm{N}$ et al. [81] showed that the prevalence of MRONJ in patients treated with antiresorptive therapy seems to be increased by low serum vitamin D levels (Table 4).

MRONJ is a problem that can occur in all oral surgery. The most important factors that could prevent it are careful patient interviewing and the preparation of the patient for surgery, with the participation of an oncologist or endocrinologist, depending on the main disease. It is recommended to check the level of vitamin D and correct the supplementation depending on the results. Additionally, the clinician can use less traumatic surgical techniques, such as lasers. 
Table 4. Literature analysis of vitamin D level and MRONJ connection.

\begin{tabular}{|c|c|c|c|c|c|c|c|c|}
\hline Author, Year & Pathology & Patients, Age & Vitamin D Level & $\begin{array}{l}\text { Diagnostics of Vitamin } \\
\text { D Imbalance }\end{array}$ & $\begin{array}{l}\text { Treatment of Vitamin } \\
\text { D Imbalance }\end{array}$ & $\begin{array}{l}\text { Vitamin } \\
\text { D Level }\end{array}$ & Positive Results-Main Pathology & Probability \\
\hline $\begin{array}{l}\text { Heim N et al., } \\
2017 \text { [81] }\end{array}$ & $\begin{array}{l}\text { Medication-related } \\
\text { osteonecrosis of } \\
\text { the jaw }\end{array}$ & $63,72.1 \pm 10.73$ & $20.49 \mathrm{ng} / \mathrm{mL}$ & Serum vitamin D level & Absent & $>30 \mathrm{ng} / \mathrm{mL}$ & $\begin{array}{l}\text { A significantly lower serum vitamin } \\
\text { D level in subjects with stage } 2 \\
\text { osteonecrosis than in patients without } \\
\text { exposed bone. }\end{array}$ & $p \leq 0.05$ \\
\hline $\begin{array}{l}\text { Bedogni, A et al., } \\
2019 \text { [84] }\end{array}$ & $\begin{array}{l}\text { Bisphosphonate- } \\
\text { related osteonecrosis } \\
\text { of the jaw }\end{array}$ & $124, \geq 18$ & Absent & $\begin{array}{l}\text { Chemiluminescent } \\
\text { immunoassay, Liaison, } \\
\text { DiaSorin, Saluggia, Italy }\end{array}$ & Absent & $>50 \mathrm{nmol} / \mathrm{L}$ & $\begin{array}{l}\text { BRONJ+ and BRONJ- patients had } \\
\text { the same frequency of vitamin D } \\
\text { deficiency and most bone } \\
\text { turnover markers. }\end{array}$ & Absent \\
\hline
\end{tabular}




\section{Conclusions}

The discovery of the "extra-osseous" effects of vitamin D has allowed us to pay attention to its significance in diseases of the maxillofacial region. The influence of vitamin D on immune processes has been discovered, along with its anti-inflammatory and antimicrobial effects. Decreasing cell proliferation and stimulating cell differentiation determines the development and course of RAS, squamous cell carcinoma of the oral cavity, periodontitis, and soft tissue healing after implantation and periodontal surgery.

Vitamin D is involved in the calcium phosphate metabolism of the bone tissue of the whole organism, and the maxillofacial region and has an active impact on the processes of osseointegration and bone remodeling. This knowledge can help clinicians to reduce the possible risk after different types of surgery, such as dental implantation and bone plasty, be more aware of complications, perform timely prophylaxis through the prompt prescription of lab tests, and include an appropriate specialist, such as an endocrinologist, in the doctors' group.

There are some works indicating the correlation between low serum levels of vitamin $\mathrm{D}$ and diseases of the maxillofacial region; to clarify the causal relationship, as well as to decide whether it is advisable to assess the status of vitamin $\mathrm{D}$ and the need to compensate for its deficiency, it is advisable to conduct further research.

Author Contributions: Conceptualization, E.D. and G.R.; validation, V.F. and S.T. and E.M.; data curation, V.F. and S.T.; writing — original draft preparation, D.T., I.A. and M.I.; writing-review and editing, E.M., E.D., I.A. and G.R. All authors have read and agreed to the published version of the manuscript.

Funding: This research received no external funding.

Institutional Review Board Statement: Not applicable.

Informed Consent Statement: Not applicable.

Data Availability Statement: Restrictions apply to the availability of these data. Data was obtained from other articles and are available from their authors or at articles' URL with the permission of authors.

Acknowledgments: We are grateful for support of our university and colleagues.

Conflicts of Interest: The authors declare no conflict of interest.

\section{References}

1. Palacios, C.; Gonzalez, L. Is Vitamin D Deficiency a Major Global Public Health Problem ? J. Steroid Biochem. Mol. Biol. 2014, 144, 138-145. [CrossRef] [PubMed]

2. Holick, M.F.; Binkley, N.C.; Bischoff-Ferrari, H.A.; Gordon, C.M.; Hanley, D.A.; Heaney, R.P.; Murad, M.H.; Weaver, C.M. Evaluation, Treatment, and Prevention of Vitamin D Deficiency: An Endocrine Society Clinical Practice Guideline. J. Clin. Endocrinol. Metab. 2011, 96, 1911-1930. [CrossRef]

3. McMahon, L.; Schwartz, K.; Yilmaz, O.; Brown, E.; Ryan, L.K.; Diamond, G. Vitamin D-Mediated Induction of Innate Immunity in Gingival Epithelial Cells. Infect. Immun. 2011, 79, 2250-2256. [CrossRef] [PubMed]

4. Krawiec, M.; Dominiak, M. Rola Witaminy D W Organizmie Ze Szczególnym Uwzględnieniem Jej Znaczenia W Patologiach Jamy Ustnej-Przegląd Piśmiennictwa. Dent. Med. Probl. 2018, 55, 419-424, in Polish. [CrossRef]

5. Roberts, I. Does Animal Experimentation Inform Human Healthcare? Observations From a Systematic Review of International Animal Experiments on Fluid Resuscitation. BMJ 2002, 324, 474-476. [CrossRef]

6. Hackam, D.G.; Redelmeier, D.A. Translation of Research Evidence From Animals to Humans. JAMA 2006, 296, 1727. [CrossRef]

7. Mal'cev, S.V.; Mansurova, G.S. Metabolizm Vitamina D I Puti Realizacii Ego Osnovnyh Funkcij. Prakt. Med. $2014,9,85$.

8. Ślebioda, Z.; Szponar, E.; Dorocka-Bobkowska, B. Vitamin D and Its Relevance in the Etiopathogenesis of Oral Cavity Diseases. Arch. Immunol. Et Ther. Exp. 2016, 64, s00005-s00016. [CrossRef]

9. Grygiel-Gorniak, B.; Puszczewicz, M. Vitamin D-A New Look in Medicine and Rheumatology. Postepy Hig. I Med. Doswiadczalnej. 2014, 68, 359-368. [CrossRef]

10. Bikle, D. Nonclassic Actions of Vitamin D. J. Clin. Endocrinol. Metab. 2009, 94, 26-34. [CrossRef]

11. Norman, A.W.; Bouillon, R. Vitamin D Nutritional Policy Needs a Vision for the Future. Exp. Biol. Med. 2010, 235, 1034-1045. [CrossRef]

12. Adams, J.S.; Hewison, M. Update in Vitamin D. J. Clin. Endocrinol. Metab. 2010, 95, 471-478. [CrossRef] [PubMed] 
13. Tang, X.; Pan, Y.; Zhao, Y. Vitamin D Inhibits the Expression of Interleukin-8 in Human Periodontal Ligament Cells Stimulated with Porphyromonas Gingivalis. Arch. Oral Biol. 2013, 58, 397-407. [CrossRef]

14. Nebel, D.; Svensson, D.; Arosenius, K.; Larsson, E.; Jönsson, D.; Nilsson, B.-O. 1 1 ,25-Dihydroxyvitamin D3 Promotes Osteogenic Activity and Downregulates Proinflammatory Cytokine Expression in Human Periodontal Ligament Cells. J. Periodont. Res. 2014, 50, 666-673. [CrossRef] [PubMed]

15. Anand, A.; Singh, S.; Sonkar, A.A.; Husain, N.; Singh, K.R.; Singh, S.; Kushwaha, J.K. Expression of Vitamin D Receptor and Vitamin D Status in Patients with Oral Neoplasms and Effect of Vitamin D Supplementation on Quality of Life in Advanced Cancer Treatment. Contemp. Oncol. 2017, 21, 145. [CrossRef]

16. Dragonas, P.; El-Sioufi, I.; Bobetsis, Y.A.; Madianos, P.N. Association of Vitamin D with Periodontal Disease: A Narrative Review. Oral Health Prev. Dent. 2020, 18, 103-114.

17. Lavie, C.J.; Lee, J.H.; Milani, R.V. Vitamin D and Cardiovascular Disease: Will it Live up to Its Hype? J. Am. Coll. Cardiol. 2011, 58, 1547-1556. [CrossRef]

18. Öztekin, A.; Öztekin, C. Vitamin D Levels in Patients with Recurrent Aphthous Stomatitis. BMC Oral Health 2018, 18, 1-5. [CrossRef] [PubMed]

19. Khammissa, R.A.G.; Fourie, J.; Motswaledi, M.H.; Ballyram, R.; Lemmer, J.; Feller, L. The Biological Activities of Vitamin D and Its Receptor in Relation to Calcium and Bone Homeostasis, Cancer, Immune and Cardiovascular Systems, Skin Biology, and Oral Health. BioMed Res. Int. 2018. [CrossRef]

20. D'yachkova, E.Y.; Trifonova, D.O.; Ibadulaeva, M.O.; Runova, G.E.; Fadeev, V.V.; Tarasenko, S.V. Vliyanie Deficita Vitamina D Na Sostoyanie Zubochelyustnoj Sistemy: Obzornaya stat'ya. Osteoporoz I Osteopatii. 2021, 24, 19-25. [CrossRef]

21. Antonova, I.N.; Grigor'yanc, A.P.; Nikitin, V.S.; Grigor'yanc, A.A. Vliyanie Deficita Vitamina D Na Harakter Techeniya Vospalitel'nyh I Reparativnyh Processov Chelyustno-Licevoi Oblasti. Med. Sovet. 2019, 12, 166-170. [CrossRef]

22. Bahramian, A.; Falsafi, P.; Abbasi, T.; Ghanizadeh, M.; Abedini, M.; Kavoosi, F.; Kouhsoltani, M.; Noorbakhsh, F.; Tabriz, F.D.; Rajaeih, S.; et al. Comparing Serum and Salivary Levels of Vitamin D in Patients with Recurrent Aphthous Stomatitis and Healthy Individuals. J. Dent. 2018, 19, 295.

23. Khabbazi, A.; G horbanihaghjo, A.; Fanood, F.; Kolahi, S.; Hajialiloo, M.; Rashtchizadeh, N. A Comparative Study of Vitamin D Serum Levels in Patients with Recurrent Aphthous Stomatitis. Egypt. Rheumatol. 2015, 37, 133-137. [CrossRef]

24. Udeabor, S.E.; Albejadi, A.M.; Al-Shehri, W.A.; Onwuka, C.I.; Al-Fathani, S.Y.; Al Nazeh, A.A.; Aldhahri, S.F.; Alshahrani, F.A. Serum Levels of 25-Hydroxy-Vitamin D in Patients with Oral Squamous Cell Carcinoma: Making a Case for Chemoprevention. Clin. Exp. Dent. Res. 2020, 6, 428-432. [CrossRef]

25. Schulze-Späte, U.; Dietrich, T.; Wu, C.; Wang, K.; Hasturk, H.; Dibart, S. Systemic Vitamin D supplementation and Local Bone Formation after Maxillary Sinus Augmentation-a Randomized, Double-Blind, Placebo-Controlled Clinical Investigation. Clin. Oral Implant. Res. 2015, 27, 701-706. [CrossRef]

26. Bryce, G.; MacBeth, N. Vitamin D Deficiency as a Suspected Causative Factor in the Failure of an Immediately Placed Dental Implant: A Case Report. J. R. Nav. Med/Serv. 2014, 100, 328-332. [CrossRef]

27. Anbarcioglu, E.; Kirtiloglu, T.; Öztürk, A.; Kolbakir, F.; Acıkgöz, G.; Colak, R. Vitamin D Deficiency in Patients with Aggressive Periodontitis. Oral Dis. 2019, 25, 242-249. [CrossRef] [PubMed]

28. Isola, G.; Alibrandi, A.; Rapisarda, E.; Matarese, G.; Williams, R.C.; Leonardi, R. Association of Vitamin D in Patients with Periodontitis: A Cross-Sectional Study. J. Periodont. Res. 2020, 55, 602-612. [CrossRef] [PubMed]

29. Patil, D.J. Clinical Implications of Vitamin D in Oral Diseases-A Review. J. Pharm. Res. Int. 2021, 103-110. [CrossRef]

30. Turgut, C.T.; Palancioğlu, A.; Yaltirik, M. D Vitamini Ve Diş Sağlı̆̆ındaki Önemi. Turk. Klinikleri. Dishekim. Bilimleri Dergisi. 2018, 24, 239-247. [CrossRef]

31. Botelho, J.; Machado, V.; Proença, L.; Delgado, A.S.; Mendes, J.J. Vitamin D Deficiency and Oral Health: A Comprehensive Review. Nutrients 2020, 12, 1471. [CrossRef] [PubMed]

32. Aydın, E.G.; Özdemir, Ö. Vitamin D and Dentistry. 2021. Available online: https://www.intechopen.com/chapters/77094 (accessed on 25 October 2021).

33. Al-Maweri, S.A.; Halboub, E.; Al-Sufyani, G.; Alqutaibi, A.Y.; Shamala, A.; Alsalhani, A. Is Vitamin D Deficiency a Risk Factor for Recurrent Aphthous Stomatitis? A Systematic Review and Meta-Analysis. Oral Dis. 2020, 26, 1116-1123. [CrossRef]

34. Krawiecka, E.; Ślebioda, Z.; Szponar, E.; Kowalska, A.; Dorocka-Bobkowska, B. Vitamin D Status in Recurrent Aphthous Stomatitis. Adv. Dermatol. Allergol./Postępy Dermatol. I Alergologii. 2017, 34, 612. [CrossRef] [PubMed]

35. Zakeri, M.; Parsian, H.; Bijani, A.; Shirzad, A.; Neamati, N. Serum Levels of Vitamin D in Patients with Recurrent Aphthous Stomatitis. Dent. Med. Probl. 2021, 58, 27-30. [CrossRef]

36. Bakr, I.S.; Zaki, A.M.; El-Moslemany, R.M.; Elsaka, R.O. Vitamin D Oral Gel for Prevention of Radiation-Induced Oral Mucositis: A Randomized Clinical Trial. Oral Dis. 2021, 27, 1197-1204. [CrossRef]

37. Rivera, C.; Oliveira, A.K.; Costa, R.A.P.; De Rossi, T.; Paes Leme, A.F. Prognostic Biomarkers in Oral Squamous Cell Carcinoma: A Systematic Review. Oral Oncol. 2017, 72, 38-47. [CrossRef]

38. Markopoulos, A.K. Current Aspects on Oral Squamous Cell Carcinoma. Open Dent. J. 2012, 6, 126. [CrossRef] [PubMed]

39. Grimm, M.; Cetindis, M.; Biegner, T.; Lehman, M.; Munz, A.; Teriete, P.; Reinert, S. Serum Vitamin D levels of Patients with Oral Squamous Cell Carcinoma (OSCC) and Expression of Vitamin D Receptor in Oral Precancerous Lesions and OSCC. Med. Oral Patologia Oral Y Cirugia Buccal. 2015, 20, e188. [CrossRef] 
40. Verma, A.; Vincent-Chong, V.K.; DeJong, H.; Hershberger, P.A.; Seshadr, M. Impact of Dietary Vitamin D on Initiation and Progression of Oral Cancer. J. Steroid Biochem. Mol. Biol. 2020, 199, 105603. [CrossRef]

41. Osafi, J.; Hejazi, A.; Stutz, D.D.; Keiserman, M.A.; Bergman, C.J.; Kingsley, K. Differential Effects of 1,25-Dihydroxyvitamin D3on Oral Squamous Cell Carcinomas In Vitro. J. Diet. Suppl. 2014, 11, 145-154. [CrossRef]

42. Fathi, N.; Ahmadian, E.; Shahi, S.; Roshangar, L.; Khan, H.; Kouhsoltani, M.; Dizaj, S.M.; Sharifi, S. Role of Vitamin D and Vitamin D Receptor (VDR) in Oral Cancer. Biomed. Pharmacother. 2019, 109, 391-401. [CrossRef]

43. Christakos, S.; Dhawan, P.; Verstuyf, A.; Verlinden, L.; Carmeliet, G. Vitamin D: Metabolism, Molecular Mechanism of Action, and Pleiotropic Effects. Physiol. Rev. 2016, 96, 365-408. [CrossRef]

44. Mostafa, B.E.D.; Abdelmageed, H.M.; El-Begermy, M.M.; Taha, M.S.; Hamdy, T.A.E.; Omran, A.; Lotfy, N. Value of Vitamin D Assessment in Patients with Head and Neck Squamous Cell Cancer before Treatment. Egypt. J. Otolaryngol. 2016, 32, $279-286$. [CrossRef]

45. Lalla, R.V.; Choquette, L.E.; Feinn, R.S.; Zawistowski, H.; Latortue, M.C.; Kelly, E.T.; Baccaglini, L. Multivitamin Therapy for Recurrent Aphthous Stomatitis: A Randomized, Double-Masked, Placebo-Controlled Trial. J. Am. Dent. Assoc. 2012, 143, 370-376. [CrossRef]

46. Mokrova, E.A. D-Vitaminnaja Nedostatochnost' I Ejo Vlijanie Na Sostojanie Parodonta. Simvol Nauki. $2016,4,4$.

47. Bashutski, J.D.; Eber, R.M.; Kinney, J.S.; Benavides, E.; Maitra, S.; Braun, T.M.; Giannobile, W.V.; McCauley, L.K. The Impact of Vitamin D Status on Periodontal Surgery Outcomes. J. Dent. Res. 2011, 90, 1007-1012. [CrossRef] [PubMed]

48. Laky, M.; Bertl, K.; Haririan, H.; Andrukhov, O.; Seemann, R.; Volf, I.; Assinger, A.; Gruber, R.; Moritz, A.; Rausch-Fan, X. SERUM LEVELS of 25-Hydroxyvitamin D are Associated with Periodontal Disease. Clin. Oral Investig. 2016, 21, 1553-1558. [CrossRef] [PubMed]

49. Jagelavičienè, E.; Vaitkevičienè, I.; Šilingaitè, D.; Šinkūnaitè, E.; Daugèlaitè, G. The Relationship between Vitamin D and Periodontal Pathology. Medicina 2018, 54, 45. [CrossRef] [PubMed]

50. Agrawal, A.A.; Kolte, A.P.; Kolte, R.A.; Chari, S.; Gupta, M.; Pakhmode, R. Evaluation and Comparison of Serum Vitamin D and Calcium Levels in Periodontally Healthy, Chronic Gingivitis and Chronic Periodontitis in Patients with and without Diabetes Mellitus-a Cross-Sectional Study. Acta Odontol. Scand. 2019, 77, 592-599. [CrossRef]

51. Elenkova, M.; Tipton, D.A.; Karydis, A.; Stein, S.H. Vitamin D Attenuates Human Gingival Fibroblast Inflammatory Cytokine Production Following Advanced Glycation end Product Interaction with Receptors for AGE. J. Periodont. Res. 2019, 54, 154-163. [CrossRef]

52. Pinto, J.P.N.S.; Goergen, J.; Muniz, F.W.M.G.; Haas, A.N. Vitamin D Levels and Risk for Periodontal Disease: A Systematic Review. J. Periodont. Res. 2018, 53, 298-305. [CrossRef] [PubMed]

53. Garcia, M.N.; Hildebolt, C.F.; Miley, D.D.; Dixon, D.A.; Couture, R.A.; Anderson Spearie, C.L.; Langenwalter, E.M.; Shannon, W.D.; Deych, E.; Mueller, C.; et al. One-Year Effects of Vitamin D and Calcium Supplementation on Chronic Periodontitis. J. Periodontol. 2011, 82, 25-32. [CrossRef]

54. Gao, W.; Tang, H.; Wang, D.; Zhou, X.; Song, Y.; Wang, Z. Effect of Short-Term Vitamin D Supplementation after Nonsurgical Periodontal Treatment: A Randomized, Double-Masked, Placebo-Controlled Clinical Trial. J. Periodont. Res. 2020, 55, 354-362. [CrossRef]

55. Meghil, M.M.; Hutchens, L.; Raed, A.; Multani, N.A.; Rajendran, M.; Zhu, H.; Looney, S.; Elashiry, M.; Arce, R.M.; Peacock, M.E.; et al. The Influence of Vitamin D Supplementation on Local and Systemic Inflammatory Markers in Periodontitis Patients: A Pilot Study. Oral Dis. 2019, 25, 1403-1413. [CrossRef] [PubMed]

56. Hiremath, V.P.; Rao, C.B.; Naik, V.; Prasad, K.V. Anti-Inflammatory Effect of Vitamin D on Gingivitis: A Dose-Response Randomised Control Trial. Oral Health Prev. Dent. 2013, 11, 61-69. [CrossRef]

57. Fretwurst, T.; Grunert, S.; Woelber, J.P.; Nelson, K.; Semper-Hogg, W. Vitamin D Deficiency in Early Implant Failure: Two Case reports. Int. J. Implant. Dent. 2016, 2, 1-6. [CrossRef]

58. Choukroun, J.; Khoury, G.; Khoury, F.; Russe, P.; Testori, T.; Komiyama, Y.; Sammartino, G.; Palacci, P.; Tunali, M.; Choukroun, E. Two Neglected Biologic Risk Factors in Bone Grafting and Implantology: High Low-Density Lipoprotein Cholesterol and Low Serum Vitamin D. J. Oral Implantol. 2014, 40, 110-114. [CrossRef] [PubMed]

59. Mangano, F.; Mortellaro, C.; Mangano, N.; Mangano, C. Is low Serum Vitamin D Associated with Early Dental Implant Failure? A Retrospective Evaluation on 1625 Implants Placed in 822 Patients. Mediat. Inflamm. 2016, 2016, 7. [CrossRef]

60. Javed, F.; Malmstrom, H.; Kellesarian, S.V.; Al-Kheraif, A.A.; Vohra, F.; Romanos, G.E. Efficacy of Vitamin D3 Supplementation on Osseointegration of Implants. Implant. Dent. 2016, 25, 281-287. [CrossRef]

61. Haussler, M.R.; Whitfield, G.K.; Kaneko, I.; Haussler, C.A.; Hsieh, D.; Hsieh, J.C.; Jurutka, P.W. Molecular Mechanisms of Vitamin D Action. Calcif. Tissue Int. 2013, 92, 77-98. [CrossRef] [PubMed]

62. Garg, P.; Ghalaut, P.; Dahiya, K.; Ravi, R.; Sharma, A.; Wakure, P. Comparative Evaluation of Crestal Bone Level in Patients Having Low Level of Vitamin D Treated with Dental Implant with or without Vitamin D3 Supplements. Natl. J. Maxillofac. Surg. 2020, 11, 199-206. [CrossRef]

63. Trindade, R.; Albrektsson, T.; Wennerberg, A. Current Concepts for the Biological Basis of Dental Implants: Foreign Body Equilibrium and Osseointegration Dynamics. Oral Maxillofac. Surg. Clin. 2015, 27, 175-183. [CrossRef] 
64. Troiano, G.; Lo Russo, L.; Canullo, L.; Ciavarella, D.; Lo Muzio, L.; Laino, L. Early and Late Implant Failure of Submerged Versus Non-Submerged Implant Healing: A Systematic Review, Meta-Analysis and Trial Sequential Analysis. J. Clin. Periodontol. 2018, 45, 613-623. [CrossRef] [PubMed]

65. Insua, A.; Monje, A.; Wang, H.L.; Miron, R.J. Basis of Bone Metabolism around Dental Implants during Osseointegration and Peri-Implant Bone Loss. J. Biomed. Mater. Res. Part A 2017, 105, 2075-2089. [CrossRef] [PubMed]

66. Mirsaeva, F.Z.; Ubajdullaev, M.B.; Vjatkina, A.B.; Fatkullina, S.S. Dental'naja Implantologija. Pod Red. Prof. F.Z. Mirsaevoj.-Ufa: Izd-Vo GBOU VPO BGMU Minzdrava Rossii. 2015, Volume 124. Available online: http:/ /library.bashgmu.ru/elibdoc/elib624.pdf (accessed on 25 October 2021).

67. Apostu, D.; Lucaciu, O.; Lucaciu, G.D.O.; Crisan, B.; Crisan, L.; Baciut, M.; Onisor, F.; Baciut, G.; Câmpian, R.S.; Bran, S. Systemic Drugs that Influence Titanium Implant Osseointegration. Drug Metab. Rev. 2017, 49, 92-104. [CrossRef]

68. Pourshahidi, S.; Yousefian, M. The Relationship Between Serum Level of Vitamin D3 and Osseointegration Around the Dental Implant. J. Oral Implantol. 2021, 47, 88-90. [CrossRef] [PubMed]

69. Hakim, L.K.; Ghasemi, T.; Bashar, S.; Dortaj, D. The Possible Role of Vitamin D Deficiency in Early Implant Failure. BioMed Res. Int. 2021. [CrossRef]

70. Amr, A.E.H. Vitamin D3 in Alveolar Bone Augmentation Performed Simultaneously with Dental Implant Placement. A Controlled Clinical and Radiographic Study. Egypt. Dent. J. 2019, 65, 3375-3392. [CrossRef]

71. Kwiatek, J.; Jaron, A.; Trybek, G. Impact of the 25-Hydroxycholecalciferol Concentration and Vitamin D Deficiency Treatment on Changes in the Bone Level at the Implant Site during the Process of Osseointegration: A Prospective, Randomized, Controlled Clinical Trial. J. Clin. Med. 2021, 10, 526. [CrossRef]

72. Boas, R.V.; Ramirez, C.; Pinheiro, A.; Machado, A.; Aguiar, T.; Mariana, C.; Casado, P. Analysis of the Effects of Vitamin D Insufficiency on Osseointegration of Dental Implants. Clin. Oral Implant. Res. 2019, 30, 113. [CrossRef]

73. Mangano, F.G.; Oskouei, S.G.; Paz, A.; Mangano, N.; Mangano, C. Low Serum Vitamin D and Early Dental Implant Failure: Is There a Connection? A Retrospective Clinical Study on 1740 Implants Placed in 885 Patients. J. Dent. Res. Dent. Clin. Dent. Prospect. 2018, 12, 174. [CrossRef]

74. Piccolotto, A.; Toyama, G.; Busato, M.; Togashi, A.Y. Effect of Vitamin D Supplementation on Clinical and Radiographic Evaluation of Oral Rehabilitation with Osseointegrated Implants. J. Health Sci. 2019, 21, 518-522. [CrossRef]

75. Waskiewicz, K.; Oth, O.; Kochan, N.; Evrard, L. Risk Factors Generally Neglected in Oral Surgery and Implantology: The High LDL-Cholesterol and the Insufficient Level of Vitamin D. Rev. Med. Brux. 2018, 39, 70-77. [CrossRef]

76. Nastri, L.; Moretti, A.; Migliaccio, S.; Paoletta, M.; Annunziata, M.; Liguori, S.; Toro, G.; Bianco, M.; Cecoro, G.; Guida, L.; et al Do Dietary Supplements and Nutraceuticals Have Effects on Dental Implant Osseointegration? A Scoping Review. Nutrients 2020, 12, 268. [CrossRef] [PubMed]

77. Markopoulos, G.; Lepetsos, P.; Perrea, D.N.; Iliopoulos, D.C.; Nikolaou, V.S. Possible Roles of Vitamin D in Bone Grafting. Cureus 2021, 13, 1-5. [CrossRef]

78. Acipinar, S.; Karsiyaka Hendek, M.; Olgun, E.; Kisa, U. Evaluation of FGF-23 and 25(OH)D 3 Levels in Peri-Implant Sulcus Fluid in Peri-Implant Health and Diseases. Clin. Implant. Dent. Relat. Res. 2019, 21, 1106-1112. [CrossRef] [PubMed]

79. Troeltzsch, M.; Woodlock, T.; Kriegelstein, S.; Steiner, T.; Messlinger, K.; Troeltzsch, M. Physiology and Pharmacology of NonBisphosphonate Drugs Implicated in Osteonecrosis of the Jaw. J. Can. Dent. Assoc. 2012, 78, 1-7.

80. Dalle Carbonare, L.; Mottes, M.; Valenti, M.T. Medication-Related Osteonecrosis of the Jaw (MRONJ): Are Antiresorptive Drugs the Main Culprits or Only Accomplices? The Triggering Role of Vitamin D Deficiency. Nutrients 2021, 13, 561. [CrossRef] [PubMed]

81. Heim, N.; Warwas, F.B.; Wilms, C.T.; Reich, R.H.; Martini, M. Vitamin D (25-OHD) Deficiency May Increase the Prevalence of Medication-Related Osteonecrosis of the Jaw. J. Cranio-Maxillofac. Surg. 2017, 45, 2068-2074. [CrossRef]

82. Michalak, F.; Hnitecka, S.; Dominiak, M.; Grzech-Lesniak, K. Schemes for Drug-Induced Treatment of Osteonecrosis of Jaws with Particular Emphasis on the Influence of Vitamin D on Therapeutic Effects. Pharmaceutics 2021, 13, 354. [CrossRef]

83. George, E.L.; Lin, Y.L.; \& Saunders, M.M. Bisphosphonate-Related Osteonecrosis of the Jaw: A Mechanobiology Perspective. Bone Rep. 2018, 8, 104-109. [CrossRef] [PubMed]

84. Bedogni, A.; Bettini, G.; Bedogni, G.; Basso, D.; Gatti, D.; Valisena, S.; Brunello, A.; Sorio, M.; Berno, T.; Giannini, S.; et al. Is Vitamin D Deficiency a Risk Factor for Osteonecrosis of the Jaw in Patients with Cancer? A Matched Case-Control Study. J. Cranio-Maxillofac. Surg. 2019, 47, 1203-1208. [CrossRef] [PubMed]

85. Demircan, S.; Isler, S.C. Changes in Serological Bone Turnover Markers in Bisphosphonate Induced Osteonecrosis of the Jaws: A Case Control Study. Niger. J. Clin. Pract. 2020, 23, 154. [CrossRef] [PubMed] 